\title{
An enriched Chaetopterus tube mat biotope in the eastern English Channel
}

\author{
E.I.S.Rees*, M. Bergmann, M. Galanidi, H. Hinz, R. Shucksmith and M.J. Kaiser \\ School of Ocean Sciences, University of Wales Bangor, Menai Bridge, Anglesey, Wales, LL59 5AB, UK. \\ *Corresponding author, e-mail: oss058@bangor.ac.uk
}

\begin{abstract}
Patches of a very dense tube mat biotope were found during fish habitat studies in the eastern English Channel. At three locations in the lows between linear sand banks off the French coast an un-described small Chaetopterus sp. occurred with small Lanice conchilega as an enriched sediment stabilizing biotope. This biotope was distinct though having similarities to other tide swept sub-tidal biotopes dominated by L. conchilega. Using cameras and side-scan sonar it was seen to overlay heterogeneous cobbles and shell hash with intermittent rippled sand veneer. The patchiness of this enriching biogenic feature contributed to the variability in trawl catches of fish.
\end{abstract}

\section{INTRODUCTION}

Classifications of sub-tidal sedimentary biotopes from north-west European shelf seas (Connor et al., 1997, 2003) include several categories wherein tube worms are so abundant that they form biogenic mats. Such mats have important ecological functions in trapping fine sediment and in provision of food or shelter for small fish (Auster et al., 1997). A worm tube dominated biotope, differing from those previously recognized, is described here from the eastern English Channel. The characterizing species in this case was a small sized, but not yet described species of Chaetopterus. It occurred together with very large numbers of small Lanice conchilega. The small form of Chaetopterus has an easily collapsed muddy tube and is distinct from the widespread large parchment tube building species (Mary E. Petersen, personal communication). Similar specimens of a small Chaetopterus, collected off Brittany had previously been sent to Dr Petersen by Professor M. Glemarec. Taxonomic descriptions of the new species are in preparation by Dr Petersen.

\section{MATERIALS AND METHODS}

Habitats were studied at a series of locations in the English Channel, previously fished by the Centre for Environment, Fisheries and Aquaculture Science
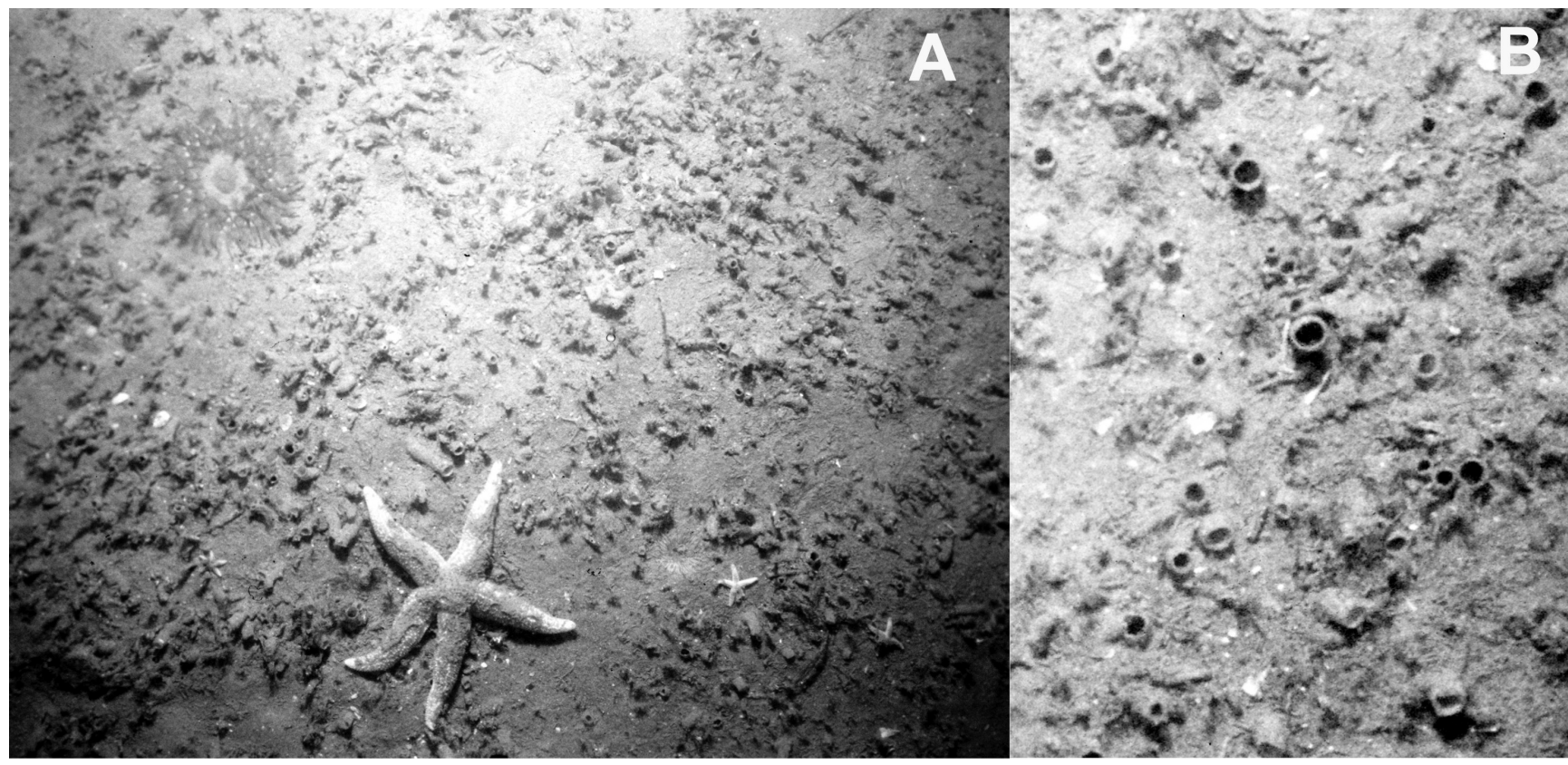

Figure 1. Photographs of the Chaetopterus tube mat biotope. Vertical views are at different enlargement scales. Image (A) $0.3 \mathrm{~m}$ across, image (B) $0.04 \mathrm{~m}$ across. 
Table 1. Stations in the eastern English Channel where the Chaetopterus tube mat biotope was found in August 2002. Positions of the camera sledge tows, and the limits of trawling areas within which the $2 \mathrm{~m}$ and $4 \mathrm{~m}$ beam trawls and grabs were deployed.

\begin{tabular}{lccc}
\hline Station code & 69 & 71 & 72 \\
\hline $\begin{array}{l}\text { Camera tows } \\
\text { Deployed }\end{array}$ & & & \\
$\quad$ Latitude & $50^{\circ} 46.85^{\prime} \mathrm{N}$ & $50^{\circ} 39.78^{\prime} \mathrm{N}$ & $50^{\circ} 33.62^{\prime} \mathrm{N}$ \\
$\quad$ Longitude & $01^{\circ} 33.16^{\prime} \mathrm{E}$ & $01^{\circ} 31.00^{\prime} \mathrm{E}$ & $00^{\circ} 32.74^{\prime} \mathrm{E}$ \\
Recovered & & & \\
$\quad$ Latitude & $50^{\circ} 47.12^{\prime} \mathrm{N}$ & $50^{\circ} 39.81^{\prime} \mathrm{N}$ & $50^{\circ} 33.35^{\prime} \mathrm{N}$ \\
$\quad$ Longitude & $01^{\circ} 33.48^{\prime} \mathrm{E}$ & $01^{\circ} 30.81^{\prime} \mathrm{E}$ & $00^{\circ} 32.73^{\prime} \mathrm{E}$ \\
$\begin{array}{l}\text { Distance towed km } \\
\text { Depths m }\end{array}$ & 0.71 & 0.57 & 0.50 \\
$\begin{array}{l}\text { Beam trawl and grab area spread } \\
\text { North-east limit }\end{array}$ & $19-20$ & 26 & $16-17$ \\
$\quad$ Latitude & $50^{\circ} 47.99^{\prime} \mathrm{N}$ & $50^{\circ} 39.67^{\prime} \mathrm{N}$ & $50^{\circ} 34.90^{\prime} \mathrm{N}$ \\
$\quad$ Longitude & $01^{\circ} 34.27^{\prime} \mathrm{E}$ & $01^{\circ} 30.94^{\prime} \mathrm{E}$ & $01^{\circ} 33.10^{\prime} \mathrm{E}$ \\
South-west limit & $50^{\circ} 46.64^{\prime} \mathrm{N}$ & $50^{\circ} 38.17^{\prime} \mathrm{N}$ & $50^{\circ} 32.12^{\prime} \mathrm{N}$ \\
$\quad \begin{array}{l}\text { Latitude } \\
\text { Longitude }\end{array}$ & $01^{\circ} 32.88^{\prime} \mathrm{E}$ & $01^{\circ} 30.33^{\prime} \mathrm{E}$ & $01^{\circ} 32.28^{\prime} \mathrm{E}$ \\
\hline
\end{tabular}

(CEFAS) for stock assessment purposes. The primary aims were to compare the diversity and consistency of fish catches with the benthic environments, and to help define the habitat requirements of three flatfish species (Hinz et al., 2003). At each site observations were made by digital side-scan sonar to indicate ground type mosaics prior to deployment of sledge mounted underwater television and still cameras. The video system was a Rovtech Seacam camera pointing obliquely forward and recording on a Sony digital 8 tape recorder. The still camera was a Photosea 1000 system arranged with the camera pointing directly downwards, with the lens $0.7 \mathrm{~m}$ above the bed, and the strobe at 60 degrees to it. Photographs were taken at 42 second intervals spread along each 30 minute camera sledge tow. Distances covered by camera sledge and trawl tows were calculated from shot and hauling positions derived from Digital Global Positioning System satellite navigation. Spread randomly along each of the previous CEFAS trawl tow lines a $0.1 \mathrm{~m}^{-2}$, day grab was deployed four times, with extra samples sometimes being taken if the side-scan showed obviously different ground types at opposite ends of the tows. These macrobenthos samples were sieved over 1-mm mesh before preservation for later laboratory processing. Four tows of 5 min duration at a speed of two knots were made with a $2 \mathrm{~m}$ small mesh beam trawl and four tows of 20 min duration at four knots were made with a $4 \mathrm{~m}$, beam trawl with a $82 \mathrm{~mm}$ cod-end mesh. Both trawls had chain matrix. Material from the trawls was sorted, enumerated and weighed at sea on a Pols motion compensated balance accurate to $1 \mathrm{~g}$. The camera tows and grabs were made prior to using the trawls at each site.

\section{RESULTS}

The Chaetopterus tubes were noted at three of the localities in the eastern English Channel sampled during a
Table 2. Numerical abundance of the more common species in grab samples as $\mathcal{N} / 0.1 \mathrm{~m}^{2}$. Columns $A, B$ and $C$ based on the five grab samples which had $>20$ Chaetopterus sp. in each. Similarity values are per cent contributions to the similarity of the grouped stations analysed by SIMPER after square-root transformation. Column $D$ has median abundances from samples with $<20$ Chaetopterus but $>50$ Lanice conchilega. Column $E$ has median abundances from samples with few or none of either tube building species.

\begin{tabular}{|c|c|c|c|c|c|}
\hline & $\begin{array}{c}\text { A } \\
\text { Median }\end{array}$ & $\begin{array}{c}\mathrm{B} \\
\text { Maximum }\end{array}$ & $\begin{array}{c}\mathrm{C} \\
\text { Similarity }\end{array}$ & $\mathrm{D}$ & $\mathrm{E}$ \\
\hline \multicolumn{6}{|l|}{$\begin{array}{l}\text { Tube building and } \\
\text { tube attached or } \\
\text { occupying }\end{array}$} \\
\hline Chaetopterus sp. & 34 & 609 & 8 & 3 & 0 \\
\hline Lanice conchlega & 416 & 2280 & 22 & 352 & 2 \\
\hline Eumida sanguinea & 101 & 178 & 10 & 53 & 0 \\
\hline Apseudes latreilli & 3 & 571 & 4 & 1 & 0 \\
\hline Phtisca marina & 17 & 90 & 4 & 6 & 0 \\
\hline \multicolumn{6}{|l|}{ Infauna } \\
\hline $\begin{array}{r}\text { Notomastus } \\
\text { latericeus }\end{array}$ & 40 & 129 & 6 & 10 & 0 \\
\hline $\begin{array}{l}\text { Nemertea } \\
\text { indet. }\end{array}$ & 14 & 136 & 3 & 15 & 6 \\
\hline $\begin{array}{l}\text { Echinocyamus } \\
\text { pusillus }\end{array}$ & 31 & 113 & 5 & 6 & 0 \\
\hline $\begin{array}{l}\text { Poecilochaetus } \\
\text { serpens }\end{array}$ & 22 & 118 & 5 & 13 & 0 \\
\hline Lagis koreni & 21 & 119 & 3 & 20 & 2 \\
\hline $\begin{array}{l}\text { Echinocardium } \\
\text { cordatum }\end{array}$ & 1 & 85 & & 10 & 0 \\
\hline Cirratulidae indet. & 20 & 29 & 5 & 9 & 0 \\
\hline Mysella bidentata & 3 & 41 & 2 & 3 & 0 \\
\hline $\begin{array}{l}\text { Urothoe } \\
\text { brevicornis }\end{array}$ & 7 & 28 & 2 & 0 & 2 \\
\hline Ensis arcuatus & 3 & 22 & 2 & 5 & 3 \\
\hline Sipuncula indet. & 1 & 24 & & 1 & 0 \\
\hline $\begin{array}{l}\text { Glycinde } \\
\text { nordmanni }\end{array}$ & 6 & 14 & & 1 & 1 \\
\hline Abra alba & 1 & 14 & & 12 & 0 \\
\hline $\begin{array}{l}\text { Aonides } \\
\quad \text { pauchibranchiata }\end{array}$ & 2 & 12 & & 0 & 0 \\
\hline \multicolumn{6}{|l|}{ Mobile epifauna } \\
\hline Ophiura ophiura & 5 & 57 & 1 & 1 & 0 \\
\hline $\begin{array}{c}\text { Abludomelita } \\
\text { obtusata }\end{array}$ & 11 & 48 & 2 & 7 & 0 \\
\hline Polinices pulchellus & 2 & 15 & & 7 & 0 \\
\hline Asterias rubens & 1 & 6 & & 0 & 0 \\
\hline
\end{tabular}

cruise on RV 'Prince Madog' in August 2002. The stations with the tube mat (Table 1) were on the French side of the eastern English Channel offshore from Boulogne and Le Touquet.

Photographs of the seabed with the Chaetopterus and Lanice conchilega tube mat biotope are shown in Figure 1. Differing scales of enlargement from the original $35 \mathrm{~mm}$ colour slides are used to illustrate the habitat and the disposition of the Chaetopterus tubes. Of 83 interpretable photographs taken at the three localities, 32 showed the dense tube mat biotope with Chaetopterus. Assuming continuity between sequential film frames during a camera sledge tow, the tube mat patches seen were spread along an estimated combined distance of $0.38 \mathrm{~km}$. As video 
image resolution was lower than from the stills camera, the Chaetopterus tubes could not always be reliably distinguished from those of other species. However, the open apertures of tubes of Chaetopterus could often be seen on video monitors as small defined dark spots in comparison with the ragged and paler appearance of the fringed tops of the L. conchilega tubes. The underwater television (UWTV) showed a dense tube biotope apparently with Chaetopterus and L. conchilega for $41 \mathrm{~min}$ of a combined total of $108 \mathrm{~min}$ when the sledge was on bottom at the three localities. For a further 39 min the video showed sparse to moderately dense tubes which appeared to be L. conchlilega. This equates to $0.45 \mathrm{~km}$ over the ground for the dense tube mat. The difference from the still camera estimate was due to film running out before the UWTV was recovered. On the enlarged still photographs, the lengths of the shadows implies that the tubes of the small Chaetopterus species often protruded from the sediment by

Table 3. Mean wet weights (grams) of fauna caught in $2 \mathrm{~m}$ and $4 \mathrm{~m}$ beam trawls, at the three stations where the tube mat was found, based on a total of 12 tows with each gear type. Species omitted where mean $<10 \mathrm{~g}$ in $2 \mathrm{~m}$ small mesh trawls and $<25 \mathrm{~g}$ in $4 \mathrm{~m}$ trawls.

\begin{tabular}{|c|c|c|}
\hline & $\begin{array}{c}2 \mathrm{~m} \text { small } \\
\text { mesh }\end{array}$ & $\begin{array}{c}4 \mathrm{~m} \text { fish } \\
\text { trawl }\end{array}$ \\
\hline \multicolumn{3}{|l|}{ Attached epifauna } \\
\hline Alcyonidium diaphanum & 60 & 1248 \\
\hline Alcyonium digitatum & & 836 \\
\hline Nemertesia antennina & 36 & 479 \\
\hline Hydralmania falcata & 11 & \\
\hline Hydrozoa indet. & & 581 \\
\hline Porifera indet. & & 291 \\
\hline Mytilus edulis & & 190 \\
\hline \multicolumn{3}{|c|}{ Mobile epifauna and infauna } \\
\hline Asterias rubens & 1261 & 6748 \\
\hline Liocarcinus holsatus & 321 & 849 \\
\hline Hinia reticulata & 87 & \\
\hline Ophiura ophiura & 65 & \\
\hline Crangon crangon & 63 & \\
\hline Maia squinado & 45 & 36 \\
\hline Pagurus bernhardus & 37 & 28 \\
\hline Diogenes pugilator & 32 & \\
\hline Necora puber & 21 & 82 \\
\hline Spisula elliptica & 14 & \\
\hline Echinocardium cordatum & 11 & \\
\hline Psammechinus miliaris & & 230 \\
\hline Cancer pagurus & & 180 \\
\hline Spatangus purpureus & & 63 \\
\hline Liocarcinus depurator & & 32 \\
\hline Ophiura albida & & 26 \\
\hline \multicolumn{3}{|l|}{ Squid and fish } \\
\hline Sepia officinalis & 322 & 5069 \\
\hline Pleuronectes platessa & 31 & 11953 \\
\hline Platichthys flesus & & 2240 \\
\hline Limanda limanda & & 482 \\
\hline Solea solea & 73 & 294 \\
\hline Microstomas kitt & & 117 \\
\hline Scophthalmus rhombus & & 39 \\
\hline Callionymus lyra & 136 & 557 \\
\hline Raja clavata & & 939 \\
\hline Trigla lucerna & & 181 \\
\hline Trisopterus minutus & & 42 \\
\hline Agonus cataphractus & 11 & 25 \\
\hline
\end{tabular}

only about $0.7-1.2$ times their aperture diameter, but some more exposed tubes were seen lying collapsed on the sediment surface.

The numbers of individuals per $0.1 \mathrm{~m}^{-2}$ of the more abundant taxa in the five grab samples that each contained at least 20 individual Chaetopterus worms are shown in Table 2. This arbitrary cut off was chosen to coincide with a break in the ranked abundance sequence. For comparison, the table also shows median abundances of the same species in samples with more than 50 Lanice conchilega but few Chaetopterus. Median abundances in samples from the same trawl tow locations with very few tubes of either species are also shown. This indicates how sparse the benthos was without the influence of the worm tubes. For the whole 14 grabs, high variance to mean ratios of 460 in the counts of Chaetopterus and 914 for L. conchilega indicated that both species had strongly aggregated distributions. Video observations confirmed this patchiness. The grabs were, however, spread over the length of the previous CEFAS trawls and not targeted at where the shorter camera tows were taken. Of the five grabs, only one seems to have coincided with the very dense Chaetopterus tube mat as seen on the photographs and video.

Table 3 lists the mean wet weights, from the beam trawls, of the more abundant taxa by different life-form groups. Some of these, such as the attached epifauna, mainly came from habitats other than the tube mat. The trawls would have swept several habitats, including patches of exposed cobbles and shells. On average the $4 \mathrm{~m}$ trawl picked up $29 \mathrm{~kg}$ of stones and $5 \mathrm{~kg}$ of shells per $20 \mathrm{~min}$ tow and $3 \mathrm{~kg}$ of stones and $2 \mathrm{~kg}$ of shells were in 5 min tows of the $2 \mathrm{~m}$ small mesh trawl.

The superficial sediment collected by grab from amongst the Chaetopterus tubes was mainly cohesive muddy sand (median phi diameter 3.04-3.09). Loss on ignition was $2.3-3.1 \%$. In the patches where the tubes were most dense the video showed black patches around burrows and black coiled worm casts indicating organic enrichment and anoxia under the sediment surface.

\section{DISCUSSION}

In this part of the eastern English Channel there is a complex of linear sand banks aligned with the tidal currents, with a range of more heterogeneous seabed types in the lows between the sand banks. These include cobbles, relict shell beds, and exposures of the underlying bedrocks (chalk and Kimmeridge clay), together with rippled sand sheets (James et al., 2002). The water here is fairly turbid with moderately strong tides $(2$ knots on mean spring tides) (Lee \& Ramster, 1981). The bed surface adjacent to the tube mat patches had asymmetrical sand ripples, with cobbles sometimes showing through the sand, or there was a lag composed mainly of shelly hash. However, within the tube mat patches the surface appeared smooth with only slight mounding. The sediment samples taken by grab indicated that the tube mat had trapped a finer and more cohesive muddy sand than would be predicted from the strength of the tidal currents. From the presence of Urticina sp. which attach to solid objects, the tube mat probably formed only a superficial fine sediment layer. 
Lanice conchilega was more widespread and the open topped Chaetopterus tubes occurred mainly where L. conchilega was also particularly abundant. On some enlarged photographs, the Chaetopterus tubes appeared to be the more abundant, but this was not so in any of the grab samples. Individuals of Chaetopterus may each have several tube openings in comparison with the single fringed top usual for L. conchilega which might account for L. conchilega being the more abundant when worms rather than tubes were counted.

Under the system of biotope classifications used for the European Nature Information System (EUNIS) (undated) there is a sub-tidal, L. conchilega dominated biotope, occurring in tide swept sand (EUNIS code A4.123). The Chaetopterus tube mat has obvious similarities to this but seems sufficiently distinct to be considered separate at level 5 in the hierarchy.

Based on side-scan sonar and video evidence, the wider extent of the individual trawl tow tracks previously used for fish stock assessment would have run over several different sedimentary habitats. These would have included rippled sands, with cobbles and shell hash both intermittently exposed at the bed surface as well as the enriched tube mat. Such superficial deposits, held together by worm tube mats, are liable to wash away when particular cohorts of key species die out, so the tube mat patches could be ephemeral. This may explain why the biotope has not been reported before in a comparatively well studied inshore sea area.

In north-west European shelf seas there are several examples of biogenic habitats where key species create niches for rich and diverse ranges of co-occurring species. In some cases these biogenic habitats even appear as 'oases' of higher biodiversity amongst wider areas of 'semidesert', impoverished through sand instability or scour. For example, a tube mat found on the edge of Nephrops norvegicus fishing grounds in the western Irish Sea had a super-abundance of small bivalves and crustaceans amongst a very dense mat of ampharetid worm tubes (Rees \& Holme, 1988). Biologically determined benthic habitats seem to be disproportionately productive and biodiverse in comparison with those at locations overwhelmingly influenced by physical sedimentary processes. In the Chaetopterus biotope described here, nine taxa had maximum abundances equivalent to over $1000 / \mathrm{m}^{-2}$. For L. conchilega the maximum was equivalent to over $22,000 /$ $\mathrm{m}^{-2}$ and for Chaetopterus sp. over $6000 / \mathrm{m}^{-2}$. The existence of such locally enriched habitats has implications for the meso-scale distribution of several commercial fish species including plaice Pleuronectes platessa (Kaiser et al., 1999) and silver hake Merluccius bilinearis (Auster et al., 1997). In the eastern English Channel the plaice biomass was highest in trawl tows with tube mat somewhere in the same general location. Spatial and temporal patchiness associated with biogenic features will influence the variability noted in trawl tows made for fish population monitoring (Hinz et al., 2003). Knowledge of where these biogenic features occur should be an important factor in ecosystem based fisheries management and interpretation of stock sampling trawl tows.

We are grateful to the Master and crew of RV 'Prince Madog' for their skill in deploying and towing the range of gear used in this project, to Ben Powell and Ray Wilton for assistance with operating the side-scan sonar. Dr Mary Petersen advised on the identity of the small Chaetopterus sp. Kerry Howell gave pre publication access to revisions of sub-tidal parts of the Joint Nature Conservation Committee Marine Habitat Classification. Clearance to operate inside territorial waters was given by the Government of France.

\section{REFERENCES}

Auster, P., Malatesta, R. \& Donaldson, C., 1997. Distributional responses to small-scale habitat variability by early juvenile silver hake, Merluccius biliearis. Environmental Biology of Fishes, 50, 195-200.

Connor, D.W., Allen, J.H., Golding, N., Lieberknecht, L.M., Northern, K.O. \& Reke, J.B., 2003. The National Marine Habitat Classification of Britain and Ireland, Version 0.303. Peterborough: JNCG. www.ince.gov.uk/marine/biotopes/ default.htm

Connor, D.W., Dalkin, M.J., Hill, T.O., Holt, R.H.F. \& Sanderson, W.G., 1997. Marine Conservation Review. Marine biotopes classification for Britain and Ireland. Vol. 2. Sublittoral biotopes. Version 97.06, Report 230. Peterborough: Joint Nature Conservation Committee.

EUNIS-European Nature Information System. Published by European Environment Agency. www.eunis.eea.eu.int/ habitats-code-browser

Hinz, H., Kaiser, M.J., Bergmann, M., Rogers, S.I. \& Armstrong, M.J., 2003. Ecological relevance of temporal stability in regional fish catches. Fournal of Fish Biology, 63, 1219-1234.

James, J.W.C. et al., 2002. GEOSYNTH: a synthesis of the geology and sediments of the Dover Strait and its hinterland. British Geological Survey, Keyworth, Nottingham. Commissioned Report GR/02/078.

Kaiser, M.J., Cheney, K., Spence, F.E., Edwards, D.B. \& Radford, K., 1999. Fishing effects in northeast Atlantic shelf seas: patterns in fishing effort, diversity and community structure. VII. The effects of trawling disturbance on the fauna associated with the tubeheads of serpulid worms. Fisheries Research, 40, 195-205.

Lee, A.J. \& Ramster, J.W., eds. 1981. Atlas of the seas around the British Isles, 5 pp. +75 sheets. London: Ministry of Agriculture, Fisheries and Food.

Rees, E.I.S. \& Holme, N.A., 1988. A local enriched macrobenthos association in the Irish Sea. In Commission of the European Communities, COST 647 Workshop, La Corruna, October 1986, pp. 173-174.

Submitted 26 April 2004. Accepted 8 December 2004. 